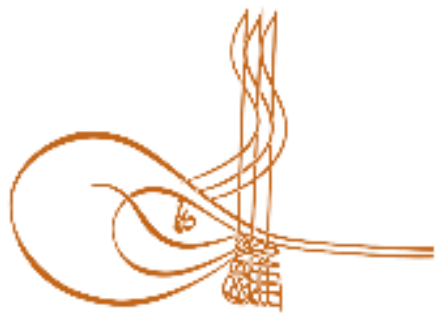

www.turkishstudies.net/education
Turkish Studies - Educational Sciences

eISSN: $2667-5609$

Research Article / Araşttrma Makalesi

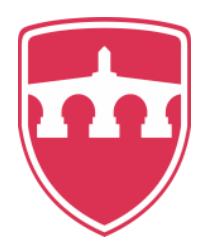

INTERNATIONAL

BALKAN

UNIVERSITY

Sponsored by IBU

\title{
Eğitim Kurumlarındaki Çatışma Durumlarının Algılanma Biçimi ve Çalışanların Motivasyonuna Etkisi"
}

\author{
Perception of Conflict Situations in Educational Institutions and Their Effect on Employee \\ Motivation
}

Ramazan Gök $^{* *}$ - Serdar Özçetin ${ }^{* * *}$

\begin{abstract}
The aim of this research is to determine the opinions of teachers and administrators working in some schools in Antalya regarding the impact of conflict on motivation in educational institutions. In accordance with this aim, in the research; the conflicting situations of the participants, the reasons for their conflicts and the ways of management, the positive and negative aspects of the conflicts, their effect on motivation and the perceptions about what has been done / should be done to make them positive have been presented. Through the research being a qualitative research model, it is aimed to gain an in-depth understanding with the phenomenology pattern, which is one of the qualitative research patterns. Within the research, "snowball or chain" sampling method, which is considered to be among the purposeful sampling methods, was preferred. Accordingly, the working group of the research consisted of 16 people working in the schools which belonged to the Antalya National Education Directorate in the 2017-2018 academic year. A Semi-structured individual interview form was prepared and the required data were collected. After the audio recordings obtained from the individual interviews were deciphered, the confirmation of the participants was taken, and then data analysis was completed by transferring them to the NVIVO 11.0 Qualitative Data Analysis Package Program. The ethics committee permission required for the conduct of the study was obtained with the decision of the Publication Ethics Committee dated 18.04.2018 and numbered 53. According to the research results; it has been concluded that in the schools the preparation and implementation of lesson programs, determination of the hall monitoring days and the assignments for ceremonies have caused conflicts. What's more, it was stated that the most important reason of the conflicts in schools was a conflict of interest among them. In the research, it has been concluded that during the conflict processes the administrators should manage the conflicts in a way that will enable both sides to win. It has also been reached that the conflicts should not always be considered as something negative, and through the conflicts experienced some original ideas could be put
\end{abstract}

\footnotetext{
* Makalenin ilk hali V. International Eurasian Educational Research Congress'de bildiri olarak sunulmuştur.

*** Dr. Öğr. Üyesi, Akdeniz Üniversitesi, Eğitim Fakültesi, Eğitim Yönetimi ve Denetimi Bölümü

Asst. Prof. Dr. Akdeniz University, Faculty of Education, Department of Educational Sciences

ORCID 0000-0002-5432-8971

rmzngk07@hotmail.com

**** * Dr. Öğr. Üyesi, Akdeniz Üniversitesi, Spor Bilimleri Fakültesi, Beden Eğitimi ve Spor Eğitimi Bölümü

Asst. Prof. Dr. Akdeniz University, Faculty of Sports Sciences, Department of Physical Education and Sports Education

ORCID 0000-0003-0797-5268

serdarozcetin@akdeniz.edu.tr

Cite as/ Atıf: Gök, R. \& Özçetin, S. (2020). Eğitim kurumlarındaki çatışma durumlarının algılanma biçimi ve çalışanların motivasyonuna etkisi. Turkish Studies - Education, 15(4), 2651-2669. https://dx.doi.org/10.29228/TurkishStudies.43588

Received/Geliş: 27 April/Nisan 2020

Accepted/Kabul: 27 August/Ağustos 2020

Copyright (C INTAC LTD, Turkey 
forward for the development of the institution and people. They stated that, as one of the negative aspects of the conflicts, they disrupted the climate of the institution, disrupted the work flow, and those conflicts within the institution caused unhappiness, unwillingness to work, a decrease in energy.

Structured Abstract: Introduction: Conflict is a concept which is estimated to be as old as human history since it is a situation that can be observed in any environment where people exist. It has an important role in the life of the individual himself/herself, in the group he/she interacts with or the community he/she lives in. The efficient management of the conflict can contribute to the development of the institutions. However; if it is not managed efficiently, it will reduce the motivation of the individuals due to the misleading of the energies of the employees within the institution, and these may cause harm to the institution. Some of the common concepts that can be deduced from the definitions of conflict are dispute, restlessness, hostility, incompatibility and disagreement (Akova and Akın, 2015). Conflict, in its basic form, is a multidimensional concept, conscious and emotional perceptions brought forward by differences (Anderson and Narus, 1990; Hanif, Adeel and Shah, 2016).

According to the contemporary management approach, conflicts contribute positively to the development of institutions if they can be managed correctly (Zhang, Chen andSun, 2015). Therefore, conflict is an important concept for the development of institutions in terms of its causes and consequences. It is possible to turn conflicts into organizational gains by managing them rationally in a competitive environment. Some of the possible gains that could be included are increasing the alternatives of decisions, arousing the interest in the current problems, developing mental activities, strengthening the innovation perspectives, increasing the communication, strengthening the relations, refreshing the motivation, promoting the democratic culture and creating a competitive environment.

According to Cenkçi, Dicle and Ökten (2013), within conflict management the preferences and leadership approach of the leader are very important. Because the conflict management approach of the leader has an impact on employees' job satisfaction, task performance, and intentions to change jobs. It is stated that the power sources used by the leaders are influential on job stress level, cooperation behavior and commitment factors to the organization. The leader has to find a way to protect the inner motivation of the employees, among different and conflicting interests, without harming relationships. According to Hom and Kinicki (2001), unresolved conflicts can reduce motivation and productivity by causing high labor turnover and job dissatisfaction.

In order for the organizations to reach the intended visions by realizing their missions motivation plays an important role. Motivating employees in the organization provides organizational efficiency and success (Serinkan, 2008: 163).

\section{Purpose}

The purpose of this research is to determine the opinions of teachers and administrators working in some schools in Antalya regarding the impacts of conflicts in educational institutions on motivation. In order to achieve this goal, the answers to the following questions were sought:

- What are the conflicting situations in the institutions?

- What are the causes of conflicts in institutions?

- What are the management ways of conflicts in institutions?

- What are the positive or negative aspects of conflicts?

- What are the effects of conflicts on motivation?

- What are the things that are done or can be done to turn the conflicts in educational institutions into positive ones?

\section{Method}

In the research, in order to explain in depth and detail how multiple participants experienced a phenomenon Qualitative Research was adopted (Christensen, Johnson and Turner, 2015, p.408; Y1ldirım and Şimşek, 2008, p.73-74). It is aimed to gain an in-depth understanding with the phenomenon (phenomenology) pattern, in order to understand the essence of what individuals experience and how they go through this 
experience regarding the impact of conflicting situations in organizations on motivation (Moustakas, 1994, p.13).

In the research, the working group of the research consisted of 16 people working in the schools which belonged to the Antalya National Education Directorate in the 2017-2018 academic year. In order to reach the volunteers who were thought to be the people that would contribute to the discovery and explanation of the events and situations by giving their opinions in detail (Yıldırım and Şimşek, 2008, p.107), the purposeful sampling method was used. Besides, as a purposeful sampling technique, "snowball or chain" sampling method, which is "effective in determining the individuals or situations that can be a rich source of information about the researcher's problem" (Yıldırım \& Şimşek, 2008, p. 111), was preferred.

Within the educational institutions, regarding the impacts of conflicts on motivation a semi-structured individual interview form was prepared in order to examine and understand the opinions of the participants in depth and to reveal their experiences and feelings (Yıldırım and Şimşek, 2008 p.127). The individual interviews were held individually (face to face) at the location (private working environment of the participants) and the times determined by the researcher and participants throughout the 2017-2018 academic year. Individual interviews were completed within six weeks and each lasted at an average of 20-30 minutes. After the audio recordings obtained from the individual interviews were deciphered, the confirmation of the participants was received, and then the data analysis was completed by transferring the data to the NVIVO 11.0 Qualitative Data Analysis Package Program.

\section{Discussion and Results}

It has been concluded that in schools the preparation and implementation of lesson programs, determination of the hall monitoring days and the assignments for ceremonies have caused conflicts. It has also been determined that not being able to prepare fair lesson plans, arrange hall monitoring days and assignments for ceremonies have often lead to conflicts within the institutions. It can be stated that such conflicts can be prevented by ensuring justice among the employees of the institutions, providing understanding and tolerance and increasing the level of communication.

According to the results of the research, the participants stated that the most important reason for the conflicts in their institutions was the conflict of interest. The participants also stated that another reason for the conflicts was the lack of communication. It can be said that the employees working in institutions do not listen to each other sufficiently during internal conflicts and consequently communication problems arise.

In the research, it has been concluded that during the conflicting processes the administrators should manage the conflicts in a way that will enable both sides to win. What's more, it has also been reached that the conflicts should not always be considered as negative outcomes, and through the conflicts experienced some original ideas could be put forward not only for the development of the institution but also the people. As one of the negative aspects of the conflicts, it has been reached that they have disrupted the climate of the institution and the work flow. The participants stated that the conflicts within the institutions caused unhappiness, unwillingness to work and a decrease in energy for them.

As a result of the research, the following aspects have also been determined that the conflicts could be turned into positive situations by the providing the participants with conflict management training, creating a corporate culture, removing prejudice, establishing empathy, determining sources of conflict, building teamwork, taking needs and requests (participation), promoting flexibility, having loud and clear institutional rules and being able to communicate.

Keywords: Education Management, Conflict, Conflict Management, Causes Of Conflict, Motivation

Öz: $\mathrm{Bu}$ araştırmanın amacı, eğitim kurumlarındaki çatışmanın motivasyon üzerindeki etkisine dair Antalya'daki bazı okullarda görev yapmakta olan öğretmen ve yöneticilerin görüşlerini belirlemektir. Bu amaç doğrultusunda araştırmada; katılımcıların çatışma durumları, çatışma nedenleri ve yönetilme biçimleri, çatışmaların olumlu ve olumsuz yönleri, motivasyon üzerine etkisi ve olumlu hale dönüştürülmesi için yapılan/yapılması gerenlere yönelik algıları ortaya konulmaktadır. Araştırma nitel bir araştırma olup, nitel araştırma desenlerinden olgubilim (fenomenoloji) deseni ile derinlemesine bir anlayış kazanmak hedeflenmiştir. Araştırmada amaçlı örneklem yöntemlerinden "kartopu veya zincir" örnekleme tercih 
edilmiştir. Buna bağlı olarak araştırmanın çalışma grubunu, 2017-2018 eğitim-öğretim yılında Antalya Milli Eğitim Müdürlüğüne bağlı okullarda görev yapan toplam 16 kişi oluşturmaktadır. Yarı yapılandırılmış bireysel görüşme formu hazırlanmış ve veriler elde edilmiştir. Bireysel görüşmelerden elde edilen ses kayıtları, deşifre edildikten sonra katılımcı teyidi alınmış, ardından NVIVO 11.0 Nitel Veri Analizi Paket Programına aktarılarak veri çözümlemeleri tamamlanmıştır. Araştırmanın yürütülmesi için gerekli olan etik kurul izni Yayın Etiği Kurulu'nun 18.04.2018 tarih ve 53 sayılı kararı ile alınmıştır. Araştırma sonuçlarına göre; okullarda ders programlarının hazırlanması ve uygulanması, nöbet gününün belirlenmesi ve tören görevlendirmelerinin çatışmalara neden olduğu sonucuna ulaşılmıştır. Okullarda yaşanılan çatışmaların en önemli nedeninin çıkar çatışması olduğunu ifade edilmiştir. Araştırmada yöneticiler çatışma sürecinde her iki tarafında kazanmasını sağlayacak şekilde çatışmaları yönetmeleri gerektiği sonucuna ulaşılmıştır. Çatışmanın her zaman olumsuz olarak görülmemesi gerektiğini ve çıkan çatışmalarla kurumun ve kişilerin gelişimi için orijinal fikirler üretildiği sonucuna ulaşılmıştır. Çatışmaların olumsuz yönlerinden birisi olarak kurum iklimini bozduğu, iş akışını bozduğu ve kurum içindeki çatışmaların çalışma isteksizliğine, enerji azalmasına ve mutsuz olunmasına neden olduğunu ifade etmişlerdir.

Anahtar Kelimeler: Eğitim Yönetimi, Çatışma, Çatışma Yönetimi, Çatışma Nedenleri, Motivasyon

\section{Giriş}

Çatışma, insanın bulunduğu her ortamda İnsanın bulunduğu her ortamda ortaya çıkabilecek kavramlardan biri de çatışmadır. Bu sebeple çatışma kavramının tarihi insanın var olduğu dönemden başlamaktadır. Sosyal bir varlık olan insan, içinde bulunduğu toplumla ve iletişim kurduğu gruplarla sürekli etkileşim hâlinde olduğundan çatışma kavramıyla da iç içedir. Hatta bazen kendisiyle bile çatışmaya girebilmektedir. Bireyin, etkileşim içinde olduğu grubun, içinde yaşadığı toplumun veya kendisinin yaşamında çatışma önemli bir role sahiptir. Çatışma, kaçınılmaz bir olgu olduğu gibi aynı zamanda çatışmanın yönetilmesi de çok önemlidir. Çatışmanın iyi yönetilmesi ile kurumların gelişimine katkı sağlanabileceği gibi iyi yönetilmediğinde ise kurumda çalışanların enerjilerinin yanlış yere yönlendirilmesine bağlı olarak bireylerin motivasyonunu düşürecektir ve bu da kurumun zarar görmesine neden olabilir.

Çatışma için yapılan tanımlardan çıkartılabilecek ortak kavramlar; anlaşmazlık, huzursuzluk, düşmanlık, uyumsuzluk ve uyuşmazlıktır (Akova ve Akın, 2015). Çatışma, temelinde çok boyutlu kavram, farklılıkların öne çıkardığı bilinçli ve duygusal algılardır (Anderson ve Narus, 1990; Hanif, Adeel ve Shah, 2016).

Çağdaş yönetim anlayışına göre çatışmalar, doğru yönetilmeleri durumunda kurumların gelişimine pozitif katkılar sağlarlar (Zhang, Chen ve Sun, 2015). Bu yüzden çatışmanın sebepleri ve sonuçları itibariyle kurumların gelişimi ileriye yönelik hedeflerin gerçekleşmesi uzun süreli varlı̆̆ını sürdürebilmesi açısından da önemli bir kavramdır. Çatışmaları, rekabet ortamı içinde rasyonel bir şekilde yöneterek örgütsel kazanımlara dönüştürmek mümkündür. Bu kazanımlar arasında; karar alternatiflerini çoğaltması, mevcut sorunlara ilgiyi artırması, zihinsel faaliyetleri geliştirmesi, yenilikçilik yönünü güçlendirmesi, iletişimi artırması, ilişkileri kuvvetlendirmesi, motivasyonu artırması, demokratik kültürü geliştirmesi ve rekabetçi bir ortam oluşturması sayılabilir.

Çatışmalar; görev çatışması, ilişki çatışması ve süreç çatışması olmak üzere üç şekilde ortaya çıkar (Moreno, Navarro, Zornoza ve Ripoll, 2009). Wit, Greer ve Jehn (2012), süreç çatışmalarının; yenilik, verimlilik, etkinlik, güven ve bağlılık gibi grup motivasyon çıtıları üzerinde kuvvetli ve negatif yönlü bir etkisinin bulunduğunu aktarmaktadırlar. He, Ding ve Yang (2014), görev çatışmasının takım motivasyonunu olumlu şekilde etkilerken, ilişki çatışmasının motivasyona zarar verdiğini ve negatif yönde etkilediğini belirtmişlerdir.

Karcıoğlu ve Alioğulları (2012), işlevsel olmayan çatışmaların olumsuz etkilerinin azaltılması için genel anlamda stratejiler geliştirilmesi gerektiğini, öğrenme ve örgütsel etkinliğin, motivasyonun artırılması için belirli bir seviyede çatışma yaratılmasının yararlı sonuçlar 
doğurabileceğini ileri sürmektedirler. Kurum motivasyonunu geliştirmek için kişiler arası ilişkileri güçlendirerek paylaşımı artırmak ve bu sayede yeni fikirlerin paylaşılmasını kolaylaştırmak gerekir (Rogers, 2003).

Ayyıldız, Cengiz ve Ustasüleyman (2006) çatışmaların, ilişkilerdeki güven duygusunu yüksek düzeyde ve negatif yönde etkilediğini, güvenin ise işbirliği ve motivasyonu yine yüksek düzeyde fakat pozitif yönde etkilediğini tespit etmişlerdir. Çatışma seviyesi yükseldikçe karşıllklı güven azalmakta, bu da işbirliği ve motivasyonu olumsuz yönde etkilemektedir.

Cenkçi, Dicle ve Ökten'e (2013) göre, çatışma yönetiminde liderin tercihleri ve liderlik yaklaşımı oldukça önemlidir. Çünkü liderin çatışma yönetimi yaklaşımının çalışanların iş tatmini, görev performansı ve iş değiştirme niyetleri üzerinde etkisi bulunmaktadır. Liderin kullandığı güç kaynaklarının; iş stresi seviyesi, işbirliği davranışı ve örgüte bağlılık faktörleri üzerinde etkili olduğu belirtilmektedir. Lider, farklı ve çatışan çıkarlar arasında, ilişkilere zarar vermeden çalışanların içsel motivasyonu korumanın bir yolunu bulmak zorundadır. Hom ve Kinicki'ye (2001) göre çözümlenmemiş çatışmalar yüksek işgücü devrine ve iş memnuniyetsizliğine neden olarak motivasyonu ve verimliliği düşürebilmektedir.

Başaran (1991) motivasyon kavramını, insanın bir yönde davranıșına yol açan, onu böyle bir davranışa iten, bir işi yapmaya istekli kılan ruhsal durumu olarak tanımlar. Motivasyonda temel amaç; çalışanların istekli ve verimli çalışmalarını sağlamak olduğu, yüksek motivasyonun, kişilerin beceri ve yeteneklerini tam kapasite kullanmalarını sağlayarak onların gelişimlerine katkıda bulunmasını sağlamaktır (Ceylan, 2002). Eğitim sisteminin hedeflere ulaşması, eğitim sisteminin yap1 taş1 olan öğretmenlerin mesleki verimliliğine bağlıdır. Öğretmenin mesleki verimliliğinin mesleki motivasyon düzeyi ile yakından ilişkili olduğu söylenebilir.

Örgütlerin misyonlarını gerçekleştirerek vizyonlarına ulaşabilmelerinde motivasyonun önemli bir rolü bulunmaktadır. Örgütte çalışanların motive edilmesi örgütsel verimliliği ve başarıyı sağlamaktadır (Serinkan, 2008: 163).

Bu bilgiler doğrultusunda araştırmanın amacı, eğitim kurumlarındaki çatışmanın motivasyon üzerindeki etkisine dair Antalya'daki bazı okullarda görev yapmakta olan öğretmen ve yöneticilerin görüşlerini belirlemektir. Bu amaca ulaşmak adına aşağıdaki sorulara cevap aranmıştır:

- Kurumlarda var olan çatışma durumları nelerdir?

- Kurumlardaki çatışma nedenleri nelerdir?

- Kurumlardaki çatışmaların yönetilme biçimleri nelerdir?

- Çatışmaların olumlu veya olumsuz yönleri nelerdir?

- Çatışmaların motivasyon üzerindeki etkileri nelerdir?

- Eğitim kurumlarındaki çatışma sebebiyle ortaya çıkan durumlardan olumlu sonuçlar elde etmek için yapılanlar ve yapılabilecekler nelerdir?

\section{Araștırma Yöntemi}

Araştırmada, birden fazla katılımonın bir fenomeni nasıl deneyimlediklerini derinlemesine ve ayrıntılı bir şekilde açıklamak için nitel araştırma benimsenmiştir (Christensen, Johnson ve Turner, 2015, s.408; Yıldırım ve Şimşek, 2008, s.73-74). Bireylerin kurumlardaki çatışma durumlarının motivasyon üzerindeki etkisi ile ilgili olarak ne yaşadıklarının ve bu deneyimi nasıl yaşadıklarının özünü anlamak (Moustakas, 1994, s.13) için, olgubilim (fenomenoloji) deseni ile derinlemesine bir anlayış kazanmak hedeflenmiştir.

Araştırmada Araştırmanın çalışma grubunu, 2017-2018 eğitim-öğretim yılında Antalya Milli Eğitim Müdürlüğüne bağlı okullarda görev yapan toplam 16 kişi oluşturmaktadır. Görüşlerini ayrıntılı biçimde aktararak olguların, olayların keşfedilmesi ve açıklanmasında yarar sağlayacak (Yıldırım ve Şimşek, 2008, s.107), kişiler olduğu düşünülen gönüllülere ulaşabilmek için amaçlı 
örnekleme yöntemi kullanılmıştır. Amaçlı örnekleme tekniği olarak da "araştırmacının problemi konusunda zengin bilgi kaynağı olabilecek birey ya da durumların saptanmasında etkili" (Yıldırım ve Şimşek, 2008, s. 111) olan "kartopu veya zincir" örnekleme tercih edilmiştir.

Eğitim kurumlarında katılımcıların çatışmanın motivasyon üzerindeki etkisine dair görüşlerini derinlemesine incelemek ve anlamak, deneyimlerini ve duygularını ortaya çıkarmak (Yıldırım ve Şimşek, 2008 s.127), amacıyla yarı yapılandırılmış bireysel görüşme formu hazırlanmıştır. Bireysel görüşmeler, 2017-2018 öğretim yılında, araştırmacı ve katılımcılar tarafından belirlenen yer (katılımcılara ait özel çalışma ortamı) ve zamanlarda bireysel olarak (yüz yüze) gerçekleştirilmiştir. Bireysel görüşmeler, altı hafta içerisinde tamamlanmış ve her biri ortalama 20-30 dakika sürmüştür. Bireysel görüşmelerden elde edilen ses kayıtları, deşifre edildikten sonra katılımcı teyidi alınmış, ardından NVIVO 11.0 Nitel Veri Analizi Paket Programına aktarılarak veri çözümlemeleri tamamlanmıştır. Bu araştırma için Akdeniz Üniversitesi Rektörlüğ̈̈ , Sosyal ve Beşeri Bilimler Bilimsel Araştırma ve Yayın Etiği Kurulu'nun 18.04.2018 tarih ve 53 sayılı kararı ile etik kurul izni alınmıştır.

\section{Bulgular}

$\mathrm{Bu}$ araştırmayla kurum içindeki çatışmaların neler olduğunu, katılımcıların çatışmaları nasıl algıladığını, çatışmaları uygun stratejiyi belirleyerek çözmenin çalışanların motivasyonuna etkisini ortaya koymak amacıyla katılımcıların görüşleri elde edilmiştir. Araştırmanın amaçları doğrultusunda yapılan nitel analizler sonucunda elde edilen bulgular temalar hâlinde sinıflandırılmıştır.

Araştırmada kurum içindeki çatışmaların neler olduğunu ortaya koymak amacıyla katılımcıların görüşleri elde edilmiştir ve elde edilen bulgular Tablo 1'de verilmiştir.

Tablo 1: Çatışma Durumları

\begin{tabular}{|c|c|c|c|c|c|c|c|c|c|c|c|c|c|c|c|c|c|}
\hline $\begin{array}{l}\text { Çatışma } \\
\text { Durumları }\end{array}$ & Z & $\frac{2}{4}$ & 3 & Z & 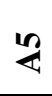 & 电 & 2 & 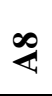 & दे & $\frac{0}{2}$ & $\bar{Z}$ & $\frac{1}{2}$ & $\frac{m}{4}$ & $\frac{\pi}{4}$ & $\frac{10}{2}$ & $\frac{0}{2}$ & $\mathbf{f}$ \\
\hline Ders Programı & & & & & $\sqrt{ }$ & & & $\sqrt{ }$ & & $\sqrt{ }$ & & $\sqrt{ }$ & & & & & 4 \\
\hline Nöbet Günü & & & & & & & & $\sqrt{ }$ & & $\sqrt{ }$ & & $\sqrt{ }$ & $\sqrt{ }$ & & & & 4 \\
\hline $\begin{array}{l}\text { Sosyal-sportif- } \\
\text { akademik } \\
\text { etkinlikler }\end{array}$ & & & & & & & & & $\sqrt{ }$ & & & & $\sqrt{ }$ & $\sqrt{ }$ & & & 3 \\
\hline Tören & & & & & & & & & & & & & & $\sqrt{ }$ & & & 2 \\
\hline Görevlendirmeleri & & & & & & $\sqrt{ }$ & & & & & & $\sqrt{ }$ & & & ل & l & ? \\
\hline
\end{tabular}

Tablo 1'de görüldügü gibi katılımcıların dördü çatışma durumları olarak ders programlarının ve nöbet günü belirlemenin okul içerisinde çatışma oluşturduğu görüşüne sahiptir. Katılımcıların üçüne göre ise sosyal-sportif-akademik etkinlikler okul içerisinde çatışma türleri olarak gözlemlendiği durumları oluşturmaktadır. İki katılımcı ise tören görevlendirmelerinin başka iki katılımcı ise veli beklentilerinin okul içerisinde çatışma durumlarını oluşturan durumlar olduğunu belirtmişlerdir. Bazı katılımcıların konuyla ilgili görüşleri aşağıdaki gibidir.

"Genellikle ders programı ile nöbet günü ve yeriyle ilgili çatışmalar yaşanıyor. Özellikle değişiklikler yapıldlğğnda sorun olabiliyor." (A8)

"ögretmenlerin ders programı ve nöbet günleriyle ilgili istekleri ve okul idarecileri ile bu konuda yaşanılan çatışmalar." (A12) 
"sosyal ve sportif etkinlikler ve veli beklentileri doğrultusunda veli- öğrenci yaşanılan problemler kurumda çatışma oluşturabiliyor." (A14)

"tören görevlendirmelerinde adaletli davranılmadığında sorunlar çıkıyor.." (A13)

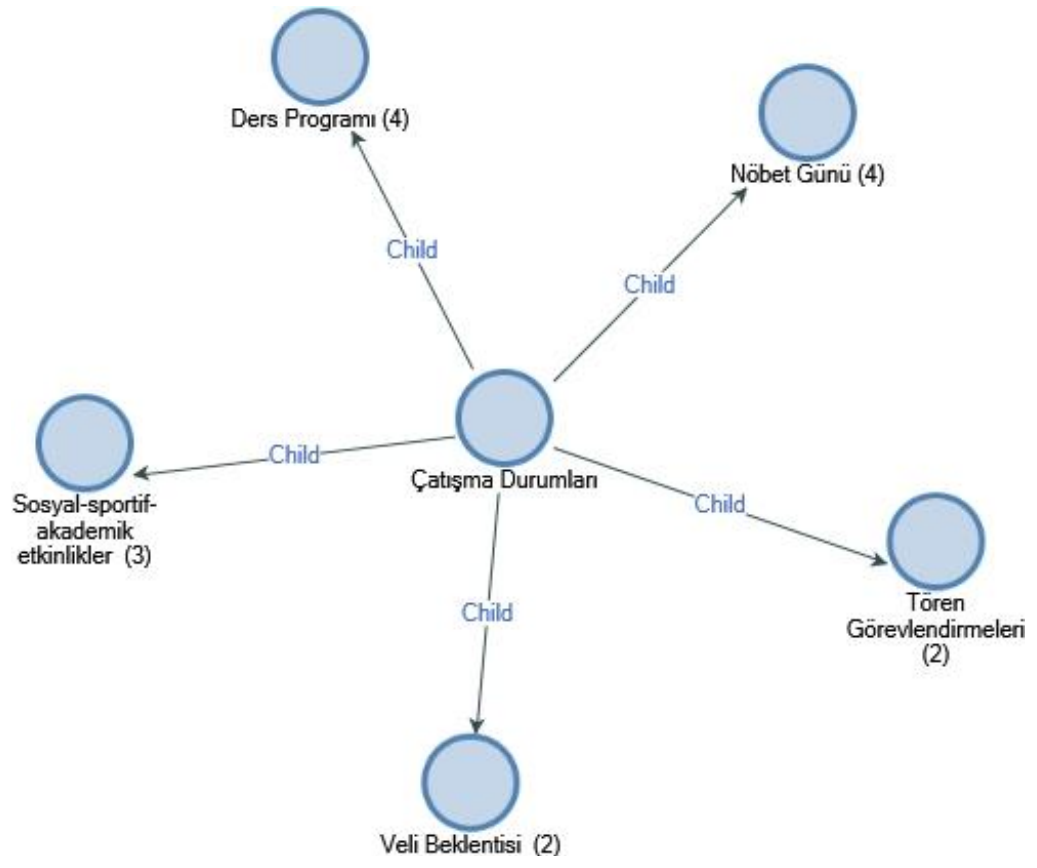

Şekil 1: Çatışma Durumları

Araştırmada kurum içindeki çatışmaların neden ortaya çıktığını belirlemek amacıyla katılımcıların görüşleri elde edilmiştir ve elde edilen bulgular Tablo 2 'de verilmiştir.

Tablo 2: Çatışma Nedenleri

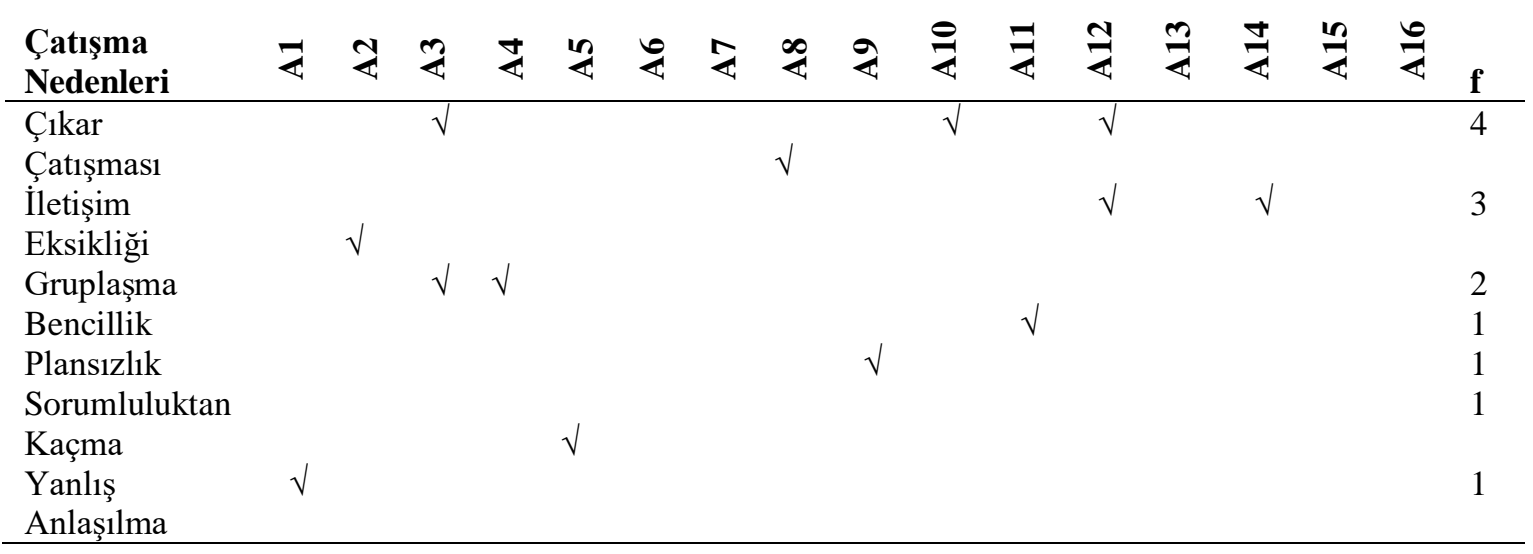

Tablo 2'de görüldüğü gibi katılımcıların dördü çatışma nedenleri olarak çıkar çatışmalarının okul içerisinde çatışmaların nedenini oluşturduğu görüşüne sahiptir. Katılımcıların üçüne göre ise iletişim eksikliğinin okul içerisinde çatışma nedeni olarak gözlemlendiği ifade edilmiştir. İki katılımcı çatışma nedeni olarak gruplaşmayı görmektedir. Birer katılımcı ise bencillik, plansızlık, 
sorumluluktan kaçma, yanlış anlaşılma durumlarının çatışma nedenleri olarak belirtmişlerdir. Katılımcıların konuyla ilgili bazı görüşleri aşağıdaki gibidir.

"herkesin kendi çıkarları doğrultusunda eşitlik anlayışının farklılık göstermesi çıkar çatışmalarını oluşturuyor." (A8)

"zaman zaman iletişim eksikliğinden kaynaklı çatışmalar olabiliyor." (A2)

"çatışmalardaki en büyük etken gruplaşmalardır." (A4)

"herkesin kendini hakl görmesi yani bencillik yapması." (A11)

"etkinliklerle sınavların aynı saatlere denk gelmesi sorun oluşturuyor plansızlık çatışmaları doğuruyor." (A9)

"genel olarak okul içerisinde yapılacak işlemlerden kaçınma yani sorumluluklardan kaçma çatışma nedenlerini doğurmaktadır. Hep başkaları yapsin diye beklenmektedir." (A5)

"yanlış anlaşılmalar nedeniyle çatışmalar olabilmektedir." (A1)

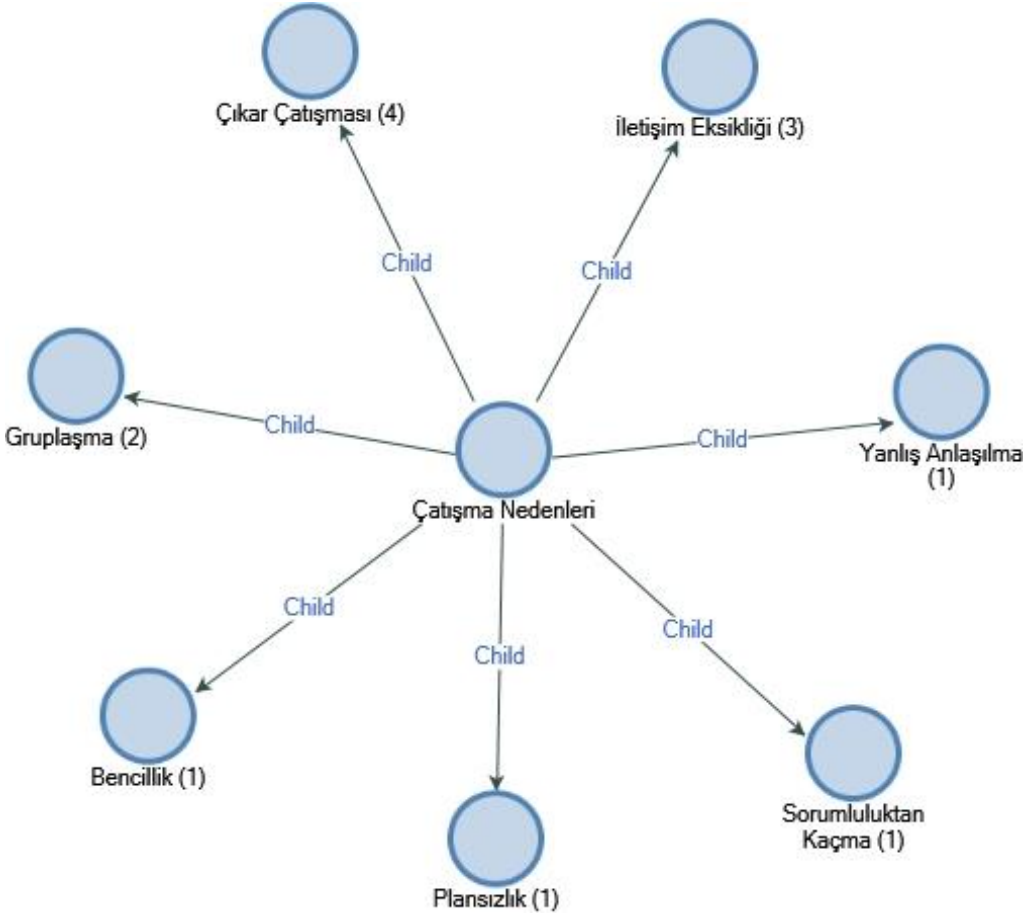

Şekil 2: Çatışma Nedenleri

Araştırmada kurum içindeki çatışmaların nasıl yönetildiğini ortaya koymak amacıyla katılımcıların görüşleri elde edilmiştir ve elde edilen bulgular Tablo 3 'te verilmiştir. 
Tablo 3: Çatışmaların Yönetilme Biçimleri

\begin{tabular}{|c|c|c|c|c|c|c|c|c|c|c|c|c|c|c|c|c|c|}
\hline $\begin{array}{l}\text { Çatışmaların } \\
\text { Yönetilme } \\
\text { Biçimleri }\end{array}$ & Z & $\frac{1}{4}$ & 2 & 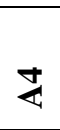 & 2 & 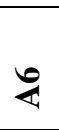 & 2 & $\sum_{4}^{\infty}$ & 2 & $\stackrel{?}{\gtrless}$ & $\bar{z}$ & $\frac{1}{4}$ & $\frac{2}{4}$ & $\frac{ \pm}{2}$ & $\frac{10}{2}$ & $\frac{0}{4}$ & f \\
\hline $\begin{array}{l}\text { İletişim } \\
\text { Kurarak }\end{array}$ & $\sqrt{ }$ & $\sqrt{ }$ & $\sqrt{ }$ & & $\sqrt{ }$ & & & $\sqrt{ }$ & & & & & & $\sqrt{ }$ & & & 6 \\
\hline $\begin{array}{l}\text { Eşitlikle } \\
\text { Profesyonel } \\
\text { Yöneticilikle }\end{array}$ & $\sqrt{ }$ & $\sqrt{ }$ & & $\sqrt{ }$ & $\sqrt{ }$ & & & & & & & & $\sqrt{ }$ & & & & $\begin{array}{l}3 \\
2\end{array}$ \\
\hline $\begin{array}{l}\text { Kazan-Kazan } \\
\text { Yöntemiyle }\end{array}$ & & & & & & & & & & $\sqrt{ }$ & & & $\sqrt{ }$ & & & & 1 \\
\hline $\begin{array}{l}\text { Yönetici } \\
\text { Müdahalesiyle }\end{array}$ & $\sqrt{ }$ & & & & & & & & & $\sqrt{ }$ & & & & & & & 1 \\
\hline $\begin{array}{l}\text { Hoşgörüyle } \\
\text { İstekleri } \\
\text { Dikkate } \\
\text { Alarak }\end{array}$ & & $\sqrt{ }$ & & & & & & & & & & & & & & $\sqrt{ }$ & $\begin{array}{l}1 \\
1\end{array}$ \\
\hline Empatiyle & & & & & & & & & & & $\sqrt{ }$ & & & & & & 1 \\
\hline
\end{tabular}

Tablo 3 'te görüldüğü gibi katılımcıların altısı iletişim kurarak kurumdaki çatışmaların yönetildiğini düşünmektedir. Katılımcıların üçüne göre ise kurum içinde eşitliği sağlayarak okul içerisinde çatışmaların yönetilme biçimlerini oluşturmaktadır. İki katılımcıya göre profesyonel yöneticilik ile çatışmalar çözümlenmektedir. Birer katılımcı ise kazan-kazan yöntemiyle, yönetici müdahalesiyle, hoşgörüyle, istekleri dikkate alarak okul içerisinde çatışmaların yönetilme biçimlerini oluşturan durumlar olduğunu belirtmişlerdir. Katılımcıların konuyla ilgili bazı görüşleri aşă̆ıdaki gibidir.

"Örgüt üyeleri arasındaki çatışmaların bir kismını yöneticiler bir kısmın üyeler kendi arasında konuşarak çözebilmektedir." (A1)

"kurumda adil davranarak çatışmaların minimuma indirildiğini düşünüyorum." (A5)

"Yöneticiler karşılıkl görüşmeler yoluyla kazan-kazan yöntemini maksimum düzeyde uygulayarak sorunları çözüyorlar." (A10)

"İ̧ini profesyonel olarak yapan kişilerle çalışmak çoğu çatışmaları çözmektedir. Kendi alanında yetkin kişilerin olmasının avantaj olduğunu düşünüyorum." (A4)

“Hoşgörü kültürü ile olumlu hale dönüşür.” (A2)

"Çalı̧̧anların istekleri dikkate alınarak." (A16)

"Karşıdaki kişiyle empati kurmaya çalı̧̧arak." (A11) 


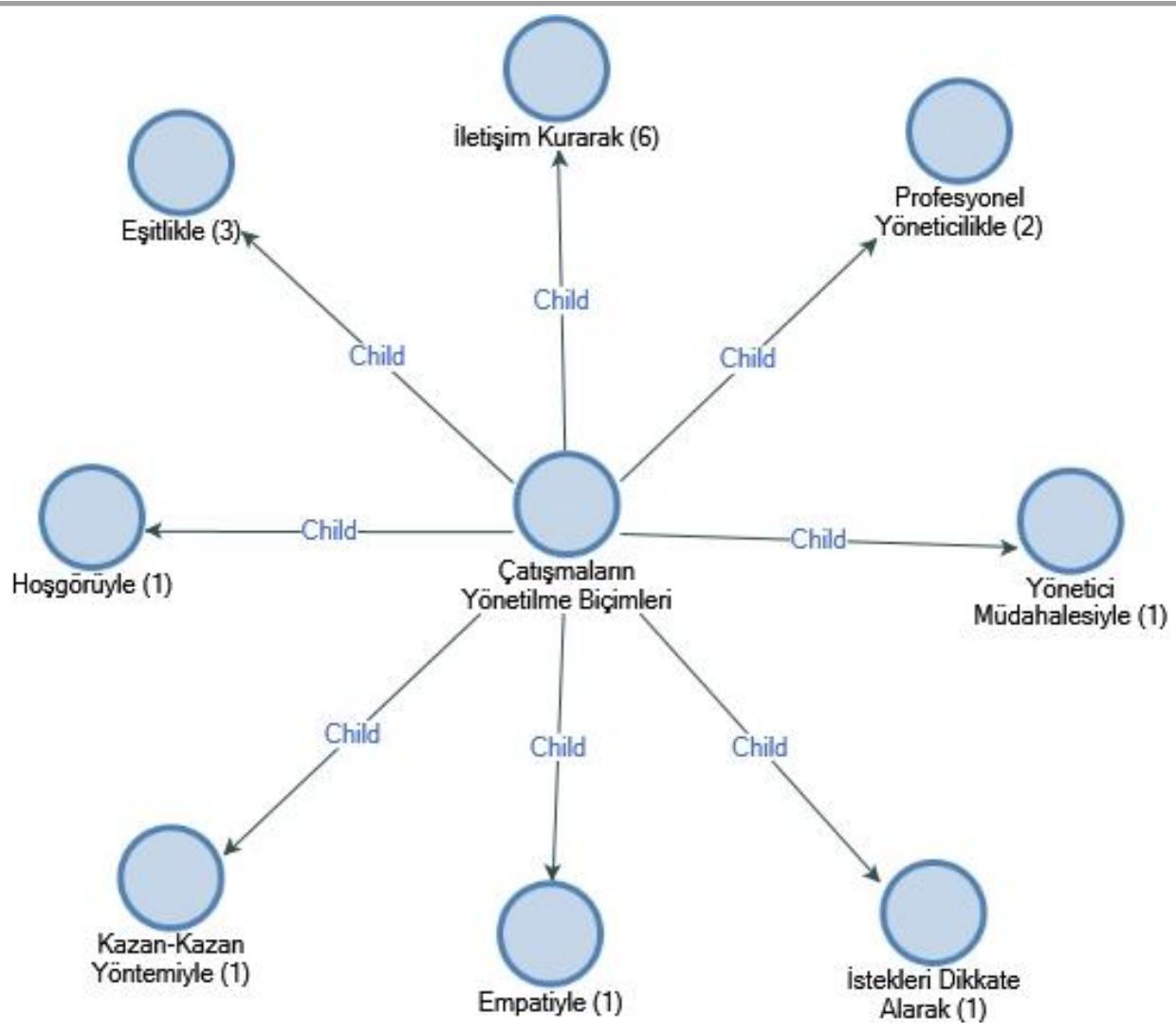

Şekil 3: Çatışmaların Yönetilme Biçimleri

Araştırmada kurum içindeki çatışmaların olumlu ve olumsuz yönlerini ortaya koymak amacıyla katılımcıların görüşleri elde edilmiştir ve elde edilen bulgular Tablo 4'te verilmiştir.

Tablo 4: Çatışmaların Olumlu ve Olumsuz Yönleri

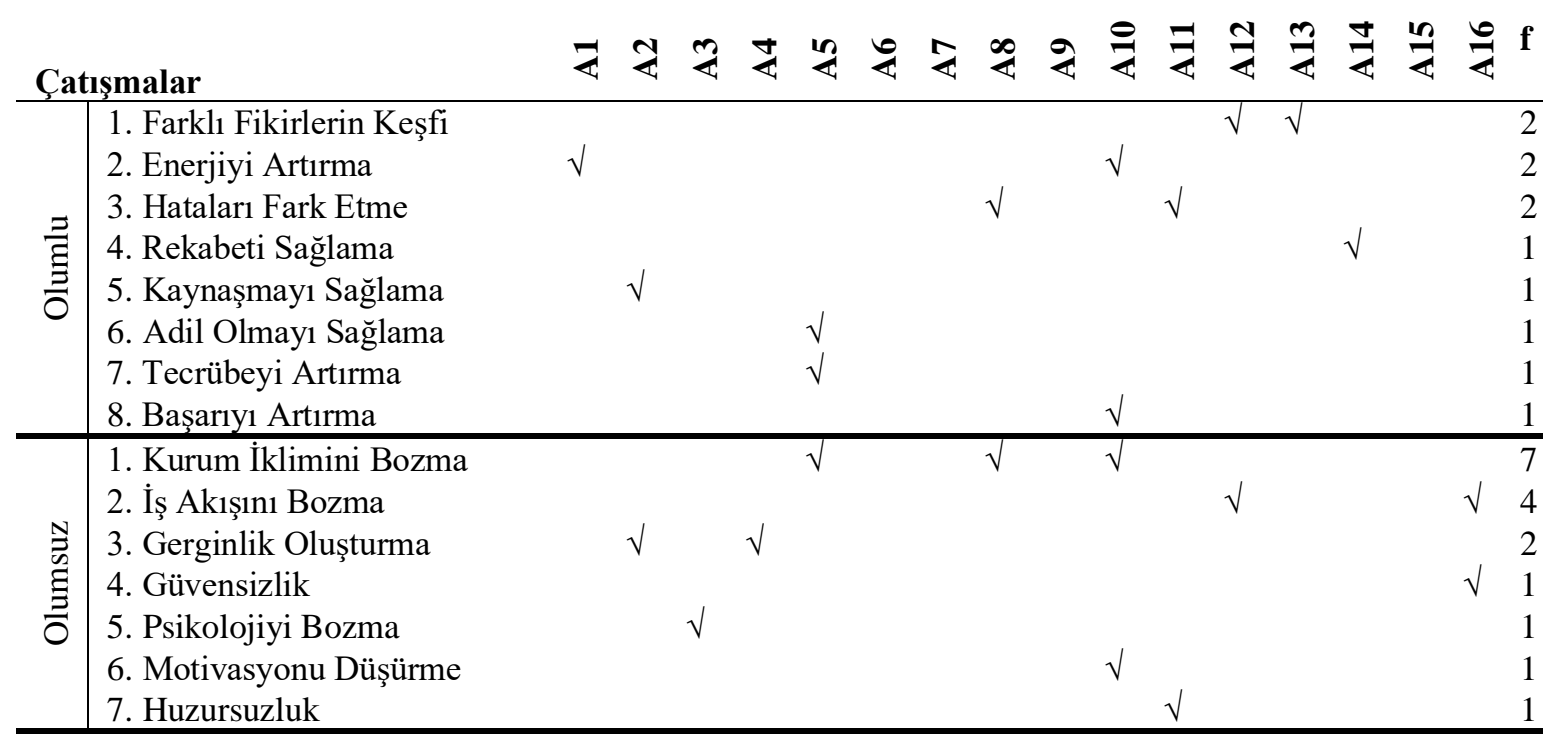

Tablo 4'te görüldüğü gibi katılımcıların görüşleri doğrultusunda çatışmanın olumlu ve olumsuz yönleri sınıflandırılmıştır. Bu görüşler doğrultusunda katılımcıların ikisi farklı fikirlerin 
keşfi, enerjiyi artırma, hataları fark etme bağlamında çatışmayı olumlu olarak algılamaktadır. Birer katılımcıda rekabeti sağlama, kaynaşmayı sağlama, adil olmayı sağlama, tecrübeyi artırma, başarıyı artırma anlamında çatışma üzerinde olumlu bir etkisi olduğunu belirtmişlerdir. Katılımcıların konuyla ilgili bazı görüşleri aşağıdaki gibidir.

"Unutmayalım, farkl yükteki bulutların çarpışmasından yağmur, farklı fikir ve isteklerin çarpışmasından yeni fikirler ortaya çıkar. Çatışma olmayan yerde ilerleme olmaz.” (A13)

"Belirli bir düzeye kadar yaşanılan çatışmalar örgüt içi enerjiyi olumlu etkilemektedir." (A1)

"Zaman zaman yapılan hatalı veya gözden kaçan uygulamaların düzeltilmesini sağlar.” (A8)

“Çatışmalar rekabeti doğurur. Bu da kurumu dinamik tutar." (A14)

"Kurum içinde çatışmalar düzgün bir şekilde çözülürse kaynaşmayı sağlar, birbirimizi daha iyi tanımış ve anlamış oluruz." (A2)

“Olumlu yanı tecrübe kazandırması, daha adil bir görev dağılımı yapmaya zorlaması.” (A5)

"Çatışmalar olumlu çözüldüğ̈̈nde barış ortamı kuruma olumlu yansıyor. Başarı çıtası yükseliyor."

Tablo 4'te görüldüğg̈ gibi katılımcıların görüşleri doğrultusunda çatıșmanın olumsuz yönleri sinıflandırılmıştır. $\mathrm{Bu}$ görüşler doğrultusunda katılımcıların yedisi kurum iklimini bozma bağlamında çatışmayı olumsuz olarak algılamaktadır. Dört katılımcı ise iş akışını bozma anlamında çatışmaları olumsuz olarak algılamaktadır. Birer katılımcıda gerginlik oluşturma, güvensizlik, psikolojiyi bozma, motivasyonu düşürme, huzursuzluk oluşturma anlamında çatışmaların olumsuz bir etkisi olduğunu belirtmişlerdir. Katılımcıların konuyla ilgili bazı görüşleri aşağıdaki gibidir.

“Çatı̧̧manın çözülmemesi durumunda kurum iklimini bozar.” (A5)

"Kırgınlıkların uzaması ile çatışmalar çözümsüz kalırsa işlerin ilerleyişini olumsuz etkileyecektir." (A12)

"Çatışmalar çözülmezse kişilerarasında gerginliğe neden olur." (A2)

"Çatışma durumları güven ortamını ortadan kaldırır." (A16)

"Psikolojik olarak olumsuz etkilemekte, psikolojiyi bozmaktadır." (A3)

"Olumsuz olduğunda öğretmenin moral ve motivasyonunu düşürüyor. Çalışma ortamına yansiyor." (A10)

“Çok fazla çatışma huzursuz bir çalışma ortamının oluşmasına sebep olabilir." (A11) 


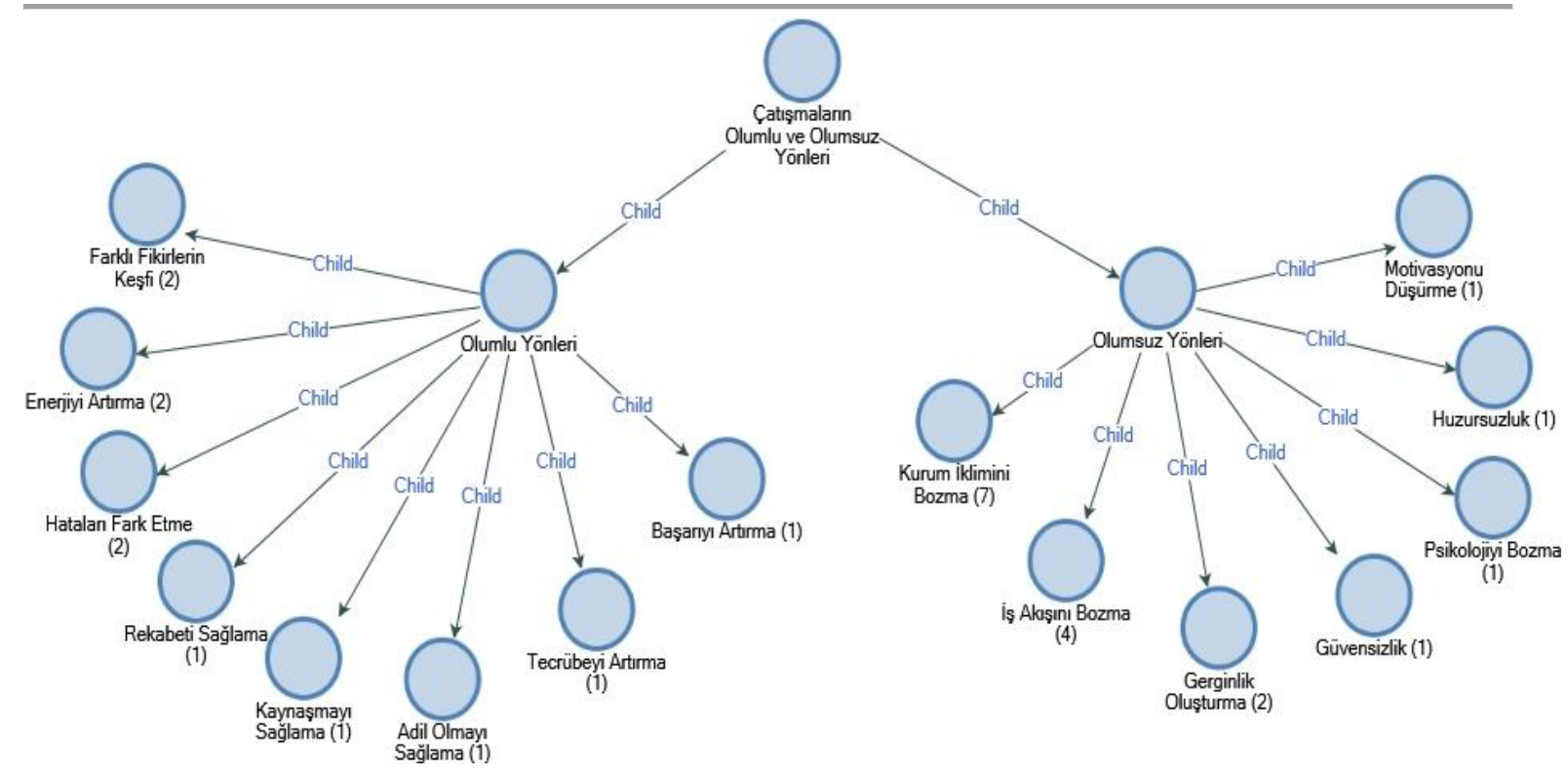

Şekil 4: Çatışmaların Olumlu ve Olumsuz Yönleri

Araştırmada kurum içindeki çatışmaların katılımcıların motivasyonunu nasıl etkilediğini ortaya koymak amacıyla katılımcıların görüşleri elde edilmiştir ve elde edilen bulgular Tablo 5 'te verilmiştir.

Tablo 5: Çatışmaların Motivasyona Etkisi

\begin{tabular}{|c|c|c|c|c|c|c|c|c|c|c|c|c|c|c|c|c|c|}
\hline $\begin{array}{l}\text { Çatışmaların } \\
\text { Motivasyona } \\
\text { Etkisi }\end{array}$ & 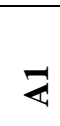 & $\frac{1}{4}$ & $\frac{3}{4}$ & 专 & 20 & 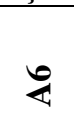 & \& & $\underset{4}{\infty}$ & 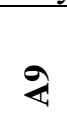 & $\frac{\varrho}{4}$ & $\bar{z}$ & $\frac{1}{4}$ & $\frac{2}{4}$ & $\frac{\pi}{4}$ & $\frac{12}{2}$ & $\frac{0}{4}$ & $\mathbf{f}$ \\
\hline $\begin{array}{l}\text { Çalışma } \\
\text { isteksizliği }\end{array}$ & & $\sqrt{ }$ & & $\sqrt{ }$ & & & & & & & & $\sqrt{ }$ & $\sqrt{ }$ & $\sqrt{ }$ & & & 5 \\
\hline $\begin{array}{l}\text { Enerjiyi } \\
\text { azaltma }\end{array}$ & $\sqrt{ }$ & & & & & & & $\sqrt{ }$ & & $\sqrt{ }$ & & & & & & & 3 \\
\hline Mutsuzluk & $\sqrt{ }$ & & $\sqrt{ }$ & & & & & & & & & & & & & & 2 \\
\hline
\end{tabular}

Tablo 5'te görüldüğü gibi katılımcıların görüşleri doğrultusunda çatışmaların motivasyona etkisi ortaya konmuştur. Katılımcıların beşi çalışma isteksizliği görüşüne sahiptir. Katılımcıların üçüne göre ise enerjiyi azaltma durumu oluşturduğunu düşünmektedir. İki katılımc1 ise mutsuzluk durumu oluşturduğunu ifade etmiştir. Çatışma durumlarının bireylerin motivasyonunu olumsuz etkilediği görülmektedir. Katılımcıların konuyla ilgili bazı görüşleri aşağıdaki gibidir.

"Çatışma ortamında çalışmak gerginliğe neden olur, motivasyonu düşürür, çalışamazsın." (A4)

"Çatışma çok sık yaşandiğında karmaşa ve kaosa neden oluyor bu da enerjimi sömürüyor." (A1)

"Beni mutsuz ediyor." (A1) 


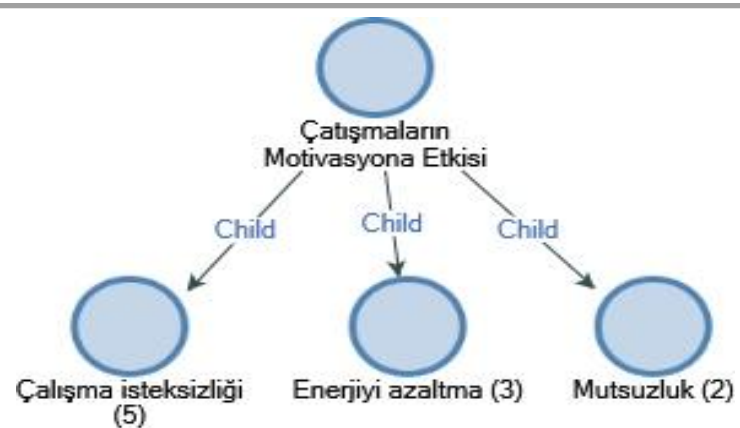

Şekil 5: Çatışmaların Motivasyona Etkisi

Araştırmada kurum içindeki çatışmaların olumlu hale dönüştürülmesi için neler yapıldığını ortaya koymak amacıyla katılımcıların görüşleri elde edilmiştir ve elde edilen bulgular Tablo 6'da verilmiştir.

Tablo 6: Çatışmaların Olumlu Hale Dönüştürülmesi İçin Yapılanlar

\begin{tabular}{|c|c|c|c|c|c|c|c|c|c|c|c|c|c|c|c|c|}
\hline $\begin{array}{l}\text { Çatışmaların } \\
\text { Olumlu Hale } \\
\text { Dönüştürülmesi } \\
\text { İccin Yapılanlar }\end{array}$ & Z & 2 & 2 & $\underset{4}{\sharp}$ & 2 & q & $\sum \infty$ & दे & $\frac{1}{2}$ & $\bar{Z}$ & $\frac{1}{4}$ & $\frac{m}{4}$ & $\frac{\pi}{4}$ & $\frac{10}{4}$ & $\frac{0}{4}$ & $\mathbf{f}$ \\
\hline İletişim Kurma & & & $\sqrt{1}$ & $\sqrt{1}$ & & & & & $\sqrt{1}$ & $\sqrt{ }$ & $\sqrt{1}$ & & $\sqrt{ }$ & & $\sqrt{ }$ & 7 \\
\hline Uzlaştırma & & $\sqrt{ }$ & & $\sqrt{ }$ & & & $\sqrt{ }$ & & $\sqrt{ }$ & & $\sqrt{ }$ & $\sqrt{ }$ & & $\sqrt{ }$ & & 7 \\
\hline Sakinleştirme & & $\sqrt{ }$ & $\sqrt{ }$ & & & & & & & & & & & & & 2 \\
\hline Arabuluculuk & $\sqrt{ }$ & & & & & & & & & & & & & & & 1 \\
\hline Objektiflik & & & & & & & $\sqrt{ }$ & & & & & & & & & 1 \\
\hline Kurum Kültürü & & & & & & & & & $\sqrt{ }$ & & & & & & & 1 \\
\hline Oluşturma & & & & & & & & & & & & & & & & \\
\hline
\end{tabular}

Tablo 6'da görüldüğü gibi katılımcıların yedisi çatışmaların olumlu hale dönüştürülmesi için iletişim kurulmaya çalışıldığı görüşüne sahiptir. Katılımcıların yedisi göre uzlaştırma yoluna gidilerek olumlu bir durum oluşturulmaya çalışılmaktadır. İki katılımcı sakinleştirme ile çatışma durumlarının olumlu hale dönüştürüldüğünü belirtmişlerdir. Birer katılımcı ise arabuluculuk, objektiflik ve kurum kültürü oluşturma ile kurum içindeki çatışmaların olumlu hale dönüştürüldügünü ifade etmişlerdir. Katılımcıların konuyla ilgili bazı görüşleri aşağıdaki gibidir.

“Çatışma yaşanılan kişiyle iletişim haline geçip, diyalogla çözülüyor.” (A4)

"okulda sesler yükselirse arkadaşlardan birini ortamdan uzaklaştırıp sakinleşmesini sağllyorum. Sonra sakinleştiğinde karşılıklı konuşup uzlaşma sağlıyoruz." (A2)

"Arabuluculuk yaparak sakin bir ortam oluşturmaya çalışlyorum." (A1)

"Gereklilikler objektif bir şekilde sunulmaya çalışıllır." (A8)

"Kurum kültürünü, amaçlarını ve hedeflerini göz önüne alıyorum." (A10) 


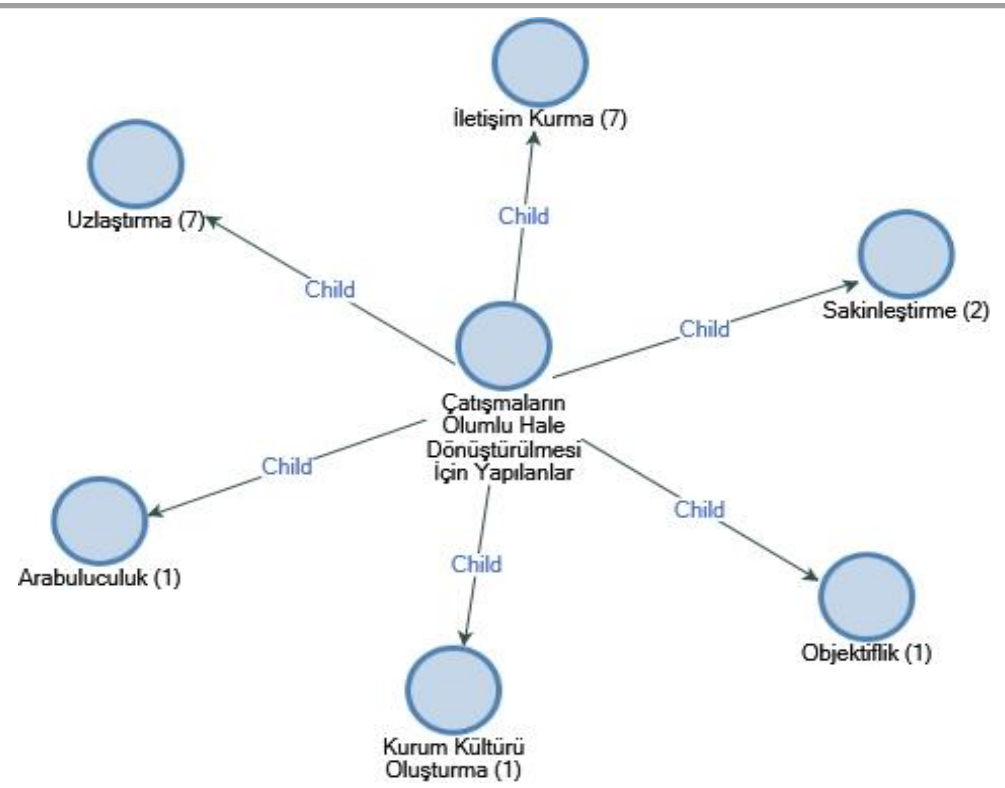

Şekil 6: Çatışmaların Olumlu Hale Dönüştürülmesi İçin Yapılanlar

Araştırmada kurum içindeki çatışmaların olumlu hale dönüştürülmesi için neler yapılabileceğini ortaya koymak amacıyla katılımcıların görüşleri elde edilmiştir ve elde edilen bulgular Tablo 7'de verilmiştir.

Tablo 7: Çatışmaların Olumlu Hale Dönüştürülmesi İçin Yapılabilecekler

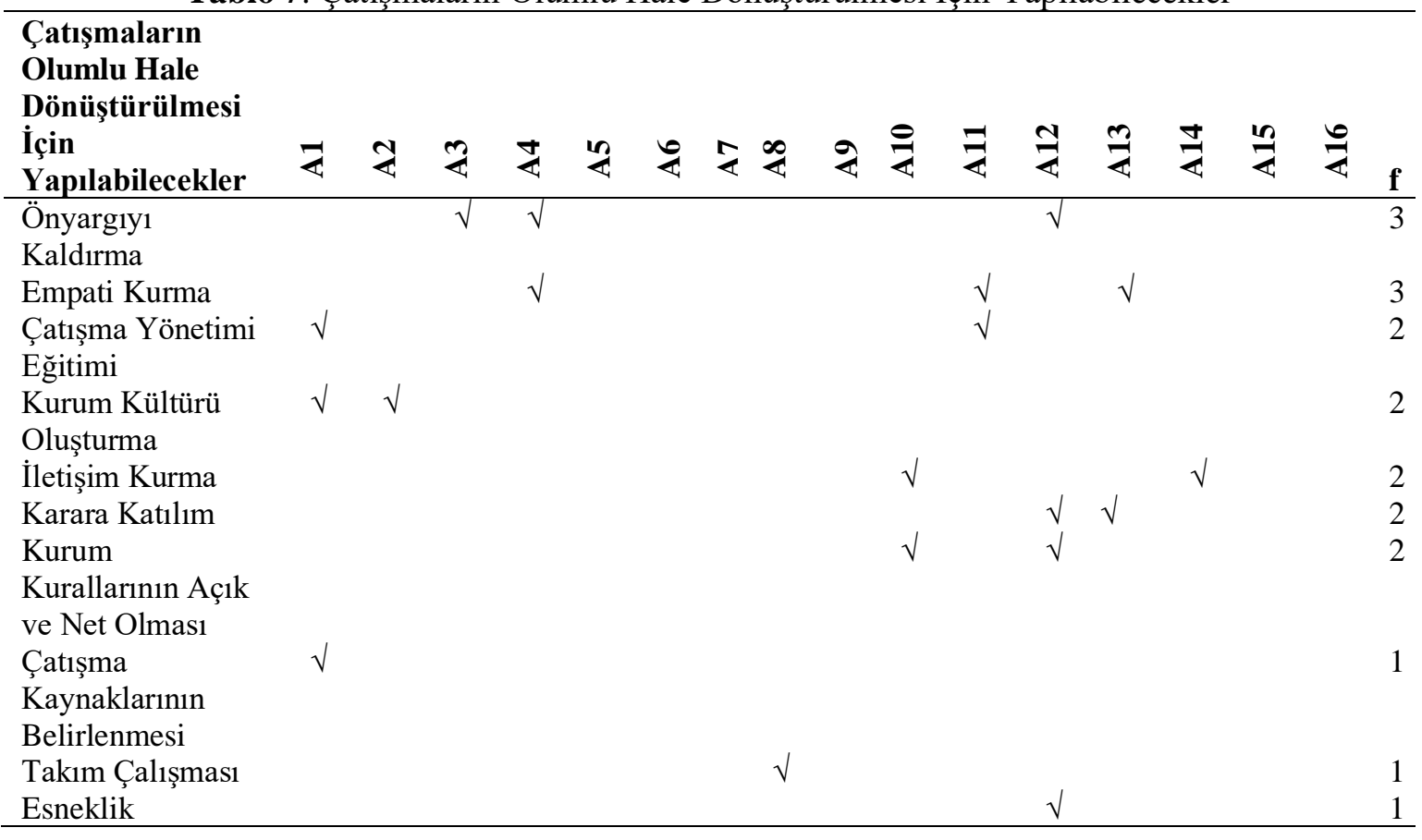

Tablo 7'de görüldüğü gibi katılımcıların görüşleri doğrultusunda kurum içinde çatışmaların olumlu hale dönüştürülmesi için neler yapılabileceği ortaya konmuştur. Buna göre üç katılımcı önyargıları kaldırma ve empati kurma ile olumlu hale dönüştürülebileceğini düşünmektedir. İkişer katılımcı çatışma yönetimi eğitimi verilerek, kurum kültürü oluşturarak, iletişim kurma, karara katılım sağlama ve kurum kurallarının açık ve net olması ile çatışmaların olumlu hale dönüştürülebileceğini düşünmektedir. Birer katılımcı ise çatışma kaynaklarının belirlenmesi, takım 
çalışması ve esneklik ile olumlu hale dönüştürülebileceğini ifade etmektedir. Katılımcıların konuyla ilgili bazı görüşleri aşağıdaki gibidir.

"Önyargı olmadan, önceden peşin hükümler vermeden, sadece kendini haklı görmeden karşı tarafi anlamaya çalışmanın önemli olduğunu düşünüyorum. ” (A3)

"İsteklerin önemsenmesiyle, duyarsız davranmama ve empati yaklaşım sergilendiğinde." (A13)

"Kurumlarda yöneticilerin çatışma yönetimini iyi bir şekilde bilmesi, kurum kültürü ve kurum enerjisi açısından önemlidir. Bu yüzden ihtiyaç duyulan kurumlarda yöneticiler böyle eğitimlere alınabilir." (A1)

"Kurum kültürünün oluşması insanların çalıştıkları kurumu benimsemesi gerekir. Hepimiz aynı kurumun başarısı için çalışıyoruz düşüncesi oluştuğunda birbirimize daha anlayışlı davranırtz, hoşgörü kültürü olursa olumlu hale dönüşür.” (A2)

"Sürekli iletişim ve bilgilendirme kanalları açık tutularak karşıllkl görüşmelerle makul olan bir orta yol bulunarak herkes görevinin gereğini yerine getirerek olumlu hale dönüştürülebilir." (A10)

"Kişilerin istekleri dikkate alınmalı, karara katılım sağlanmalı." (A12)

"Kurum kuralları açık ve anlaşıllır olmall, kişilere göre değişkenlik göstermemeli." (A12)

"En çok hangi konularda çatışmalar yaşanıllyor bunlar belirlenerek o konulara yoğunlaşılabilir." (A1)

"Okullardaki yönetici, ögretmen ve diğer çalışanlar bir takım halinde düşünürse çatışma çıkmaz, çıksa bile kısa sürede çözüme kavuşturulur." (A8)

“Gerekli zamanlarda gerekli esneklik gösterilmeli.” (A12)

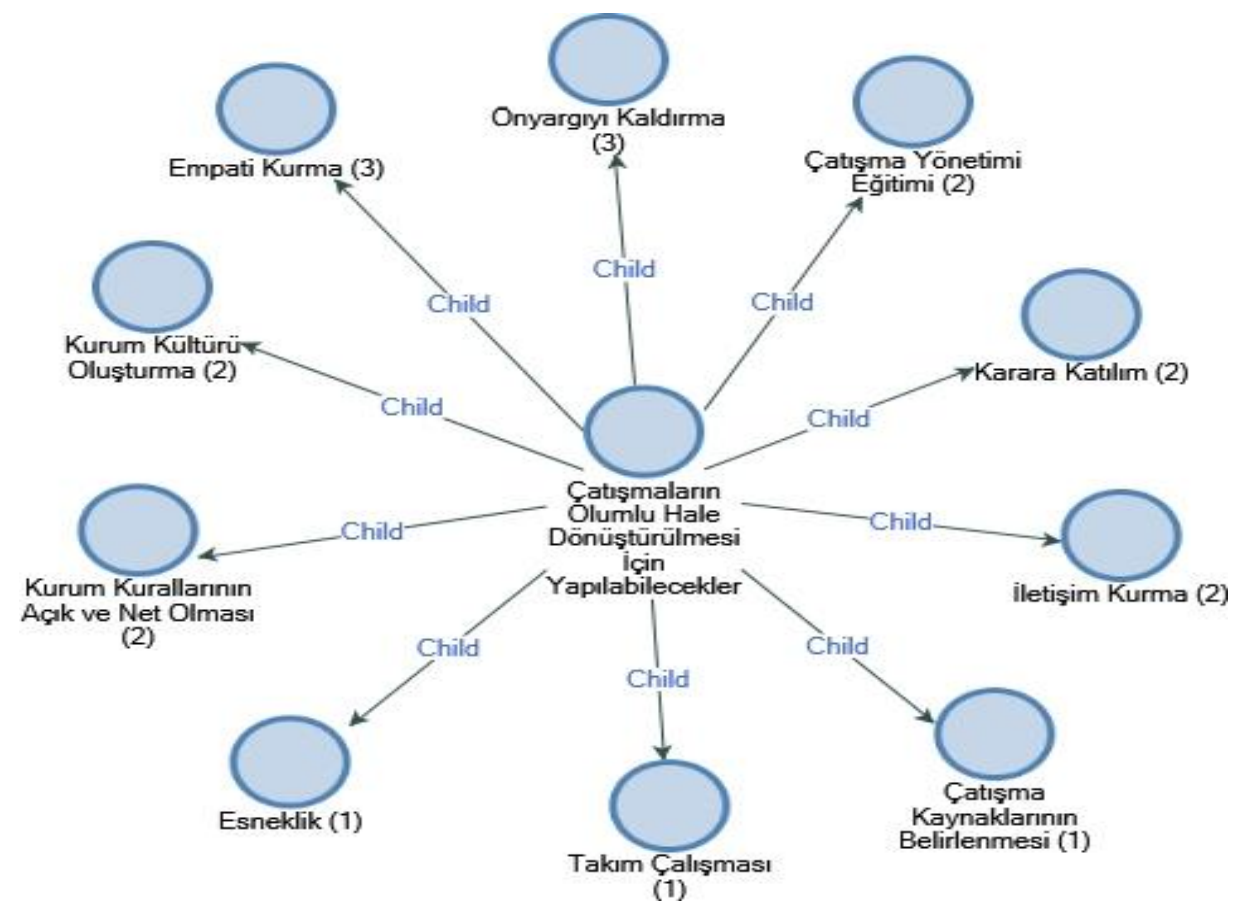

Şekil 7: Çatışmaların Olumlu Hale Dönüştürülmesi İçin Yapılabilecekler 


\section{Tartışma ve Sonuçlar}

İnsan yaşamı boyunca birçok farklı alanda çatışma olgusuyla baş başa kalır. Bazı durumlarda çatışma olgusu fark edilirken bazı durumlarda bu olgunun farkında olunmayabilir. Yine de sosyal bir varlık olan insan, çatışmayı fark ettiği durumlarda buna çözüm yolu arar. Özellikle bir parçası olduğu örgüt ya da gruptaki çatışmayı çözmek, insan için bir başarı unsurudur. Ayrıca bunu çözerken uygun yöntemler tercih edilmelidir. Örgütteki çatışmaları sağlıklı bir şekilde çözmek örgüt başarısını da olumlu yönde etkileyecektir. Bununla birlikte örgütün paydaşlarının motivasyonu açısından da çatışma durumun çözülmesi büyük önem arz eder. Örgüt içerinde çatışmayı yok saymak yerine her zaman bunun üzerine gidip çatışma durumunu doğru şekilde yönetmek gerekir.

Katılımcılar, kurumlarında yaşanan ve yaşanmaya devam eden en önemli çatışma türü ders programlarının hazırlanması ve uygulanması süreci olarak ifade etmişlerdir. Kurumlarda yöneticiöğretmen ya da öğretmen-öğretmen arasında ders programları ile ilgili sıklıkla çatışmaların yaşandığı görülmektedir. Yine katılımcılar tarafindan nöbet gününün belirlenmesi ile ilgili de sıklıkla çatışmalar yaşandığ belirtilmiştir. Okullarda öğretmenlerin tören görevlendirmelerinin çatışmalara neden olduğu sonucuna ulaşılmıştır. Okullarda adaletli bir ders programı, nöbet günü ve tören görevlendirmesi dağılımının yapılmaması sık sık çatışmaların ortaya çıkmasına sebep olmaktadır. Kurumlarda çalışanlar arasında adaletin sağlanmasıyla, anlayış ve hoşgörü sağlanmasıyla ve iletişim düzeyinin artırılmasıyla bu tür çatışmaların önüne geçilebileceği söylenebilir. Güllüoğlu (2013)'nun "Kayseri'de Hizmet Veren Özel İlköğretim Okulu Öğretmenlerinin Çatışma Faktörlerinin ve Çatışma Yönetimi Stratejilerinin Analizi" adlı çalışmasındaki okuldaki uygulamalar ve görevler konusunda eşit görev dağılımını sağlamak için öğretmenler işbirliği yapmaya ve fikir alışverişi yapmaya özendirilmelidirler sonucu ile paralellik göstermektedir.

İnsanların toplu olarak yaşadığı yerlerde çıkar çatışması olması doğal bir süreçtir. Araştırmanın sonuçlarına göre katılımcılar, kurumlarında yaşadığı çatışmaların en önemli nedeninin çıkar çatışması olduğunu ifade etmişlerdir. Katılımcılar çatışmaların diğer bir sebebini ise iletişim eksikliği olduğunu belirtmişlerdir. Kurumlarda çalışanların kurum içi çatışmalarda birbirlerini yeterince dinlemedikleri ve buna bağlı olarak iletişim sorunlarının ortaya çıktığı ifade edilebilir. $\mathrm{Bu}$ sonuç Ceylan, Ergün ve Alpkan (2000)'in yaptığı "Çatışmanın Sebepleri ve Yönetimi” adlı çalışmasındaki; ön plana çıkan bir başka çatışma sebebi iletişim eksikliğidir. İletişim eksikliği beraberinde kaçınılmaz olarak iletişim sorunlarını da getirecek ve örgütün bir bölümündeki böyle bir bozukluk tamamına sirayet ederek zincirleme çatışmalara yol açacaktır sonucuyla benzerlik göstermektedir. $\mathrm{Bu}$ bağlamda yöneticiler; kurumlarındaki çalışanlar arasında meydana gelen uyuşmazlıkları gözlemleyip, çalışanların çatışmayı yönetip yönetemediklerini takip ederek, gerektiğinde çatışmaların nedenlerini doğru bir şekilde tespit ederek çatışma durumlarını yönetebilmelidir.

Katılımcılar kurumlarında yaşanılan çatışmaları iletişim kurarak yani konuşarak, dinleyerek, karşısındakini anlayarak çözdüklerini ifade etmişlerdir. Bu durumda yöneticiler ve çalışanlar arasında etkili iletişim becerileri geliştirilerek çatışmalar çözüme ulaştırılabilir. Yöneticiler kurumlarındaki çatışmaları çözerken çalışanlar arasında adaletli şekilde davrandıklarını belirtmişlerdir. Kurumlarında adaletin olduğunu gören ve hisseden çalışanların motivasyonlarının da yüksek olması beklenir. Bu nedenle kurum gelişimi için çatışmaların etkili bir şekilde yönetilmesi önemlidir. Katılımcılara göre yöneticiler kurumlarındaki çatışmaları çözerken kazan-kazan yöntemini uyguladıklarını belirtmişlerdir. Araştırmada yöneticiler çatışma sürecinde her iki tarafında kazanmasını sağlayacak şekilde çatışmaları yönetmeleri gerektiği sonucuna ulaşılmıştır.

Katılımcılar kurum içindeki çatışmaların olumlu yönlerinden biri olarak farklı fikirlerin ortaya çıkmasını vurgulamışlardır. Çatışmanın her zaman olumsuz olarak görülmemesi gerektiğini ve çıkan çatışmalarla kurumun ve kişilerin gelişimi için orijinal fikirler üretildiği sonucuna ulaşılmıştır. Katılımcılar kurum içindeki çatışmaların olumlu yönlerinden bir diğeri olarak da 
kurumdaki enerjiyi arttırdığını belirtmişlerdir. Katılımcıların kurum içindeki çatışmaların olumlu yönleri olarak diğer ifadeleri ise hataların fark edilmesini sağlama, kaynaşmayı sağlama ve adil olmayı sağlamaktır. Bu bağlamda çatışmaların kuruma katkı sağlayan yanlarının olduğu da söylenebilir.

Katılımcılar kurum içindeki çatıșmaların olumsuz yönlerinden birisi olarak kurum iklimini bozması olduğunu ifade etmişlerdir. Kurumlarda çalışanlar için kurum ikliminin olumlu olması verimliliği arttıracaktır. Yöneticiler olumlu bir kurum kültürü oluşturabilirlerse çatışmaların azalacağ 1 söylenebilir. Katılımcılara göre kurum içindeki çatışmaların diğer olumsuz yönü ise iş akıșını bozmasıdır. Bu bağlamda kurumlar hedeflerine ulaşabilmesi ve sistemin doğru bir şekilde ilerlemesi için çatışmaların olumsuz yönlerinin fark edilerek iyi bir şekilde yönetilmesi gerekmektedir. Bu sonuç Ceylan, Ergün ve Alpkan (2000)'in çalışmasındaki, çalışanların iş tanımları ile ilgili olarak görev, yetki ve sorumluluklardaki belirsizlikler ve karışıklıklar çalışanlar arasında yetki kargaşası, görevlerin aksaması ya da çabaların teksiri gibi olumsuzluklara yol açabilecek bir etkiye sahiptir sonucu ile benzerlik göstermektedir. Katılımcılar kurum içindeki çatışmaların diğer olumsuz yönleri olarak da gerginlik oluşturduğu, güvensizlik yarattığı, kişileri psikolojik olarak etkilediği, motivasyonu düşürdüğü ve huzursuzluk yarattığını ifade etmiş̧lerdir.

Katılımcılar kurum içindeki çatışmaların çalıșma isteksizliğine, enerji azalmasına ve mutsuz olunmasına neden olduğunu ifade etmişlerdir. Kurumlardaki çatışmaların tümünün olumsuz sonuçlara neden olduğu görülmektedir. Bu bağlamda kurumdaki çatışmalar olumsuz bir ortamın oluşmasına neden olacağı aynı zamanda kurumun durağan bir yer haline geleceği söylenebilir. Bu sonucu Akova ve Akın (2015)'ın “Çatışma Yönetimi, Yönetsel ve Örgütsel Etkinliği Geliştirme Yöntemleri" adlı çalışmasının; çatışma, işletmelerde amaçlardan sapma, maliyetlerin artması, moral seviyesinin düşmesi, güvensizlik ve şüpheciliğin artması, farklılıkların derinleşmesi, işbirliğinin zarar görmesi, çalışan sağlığının bozulması ve verimliliğinin düşmesi gibi olumsuzluklara da yol açabilmektedir sonucu desteklemektedir.

Katılımcılar kurum içindeki çatışmaların iletişim kurma, uzlaştırma, sakinleştirme, arabuluculuk, objektif olma ve kurum kültürü oluşturma ile olumlu hale dönüştürülmesi için kurumlarında kullanıldığını söylemişlerdir. Kurumlardaki çatışmaların çözülebilmesi için çalışanlarla iletişim halinde olmanın önemli bir araç olduğu sonucuna ulaşılabilir. Bu durum Özgan ve Aslan (2008)'1n “İlköğretim Okul Müdürlerinin Sözlü İletişim Biçiminin Öğretmenlerin Motivasyonuna Etkisinin İncelenmesi” adlı çalışmasında elde ettiği toplanan verilere bakıldığında okul müdürlerinin sözlü iletişim biçimlerinin öğretmenlerin motivasyonu üzerinde etkisinin olduğu görülmüștür sonucuyla paralellik göstermektedir. Özdemir (2018)'inde "Okullarda Öğretmenlerin Yaşadığ Çatışma ve Çatışma Yönetim Stilleri” adlı çalışmasında ulaștığı sonuçlardan biri Hizmet içi eğitim kapsamında öğretmenlere arabuluculuk, iletişim ve çatışma çözme eğitimleri verilebilir sonucu ile benzerlik göstermektedir.

Katılımcılar çatışmaların olumlu bir hale dönüştürülmesi için önerileri; çatışma yönetimi eğitimi, kurum kültürü oluşturma, önyargıyı kaldırma, empati kurma, çatışma kaynaklarının belirlenmesi, takım çalışması, ihtiyaç ve isteklerinin alınması (karara katılım), esneklik, kurum kurallarının açık ve net olması, iletişim kurma olarak ifade etmişlerdir. Bu bağlamda eğitim-öğretim başlangıcındaki öğretmenler kurulunda yıl içinde yapılacak etkinliklerin ve tören vb. görevlendirmelerin açık ve net bir şekilde planlanması gerektiği söylenebilir. Karcıŏlu ve Alioğulları (2012)'nın yaptığı çalışmada da bu sonuca benzer şekilde, çatışmaların çözümü için yöneticilerin çalışanların görev dağılımında, yetkilerin belirlenmesinde daha açık ve net olması ve bunu çalışanlarına iletmesi gerektiğini belirtmişlerdir. Aynı zamanda Kurumlarda çalıșanlara çatışma yönetimi eğitiminin verilmesinin ve kurum kültürü ile ilgili ortak etkinlikler yapmanın gerektiği sonucuna varılabilir. Bu durum Bülbül ve Tunç (2017)'un yaptığı Bölümler arası Çatışmanın Yenilik Performansına Etkisi amaç birliği sağlanması, alınan kararlara üst yönetimin destek vermesi, 
bölümler arası iletişim ve işbirliğinin artırılması, doğru ve güvenilir bilgi paylaşılması çatışmayı azaltmada önemli bir role sahip olduğu sonucuyla benzerlik göstermektedir. Bu bağlamda hizmet içi eğitimlerle de çatışma ile ilgili seminerlerin verilmesi gerektiği söylenebilir.

\section{Kaynakça}

Akova, O., Akın, G. (2015). Çatı̧̧ma Yönetimi, Yönetsel ve Örgütsel Etkinliği Geliştirme Yöntemleri, Editörler: Özer, K.O., Hızıroğlu, M., Saladamlı, A., Adra Yayıncılık.

Anderson, J. C., Narus, J. A. (1990). A Model of Distributor Firm and Manufacturer Firm Working Partnership, Journal of Marketing, 54, 42-58. https://doi.org/10.1177/002224299005400103

Ayyıldız, H.; Cengiz, E. ve Ustasüleyman, T. (2006), “Üretim ve Pazarlama Bölüm Çalışanları Arası Davranışsal Değişkenlerin Firma Performansı üzerine Etkisine İlişkin Yapısal Bir Model Önerisi”, Muğla Üniversitesi Sosyal Bilimler Enstitüsü Dergisi, 17, 21-38. https://doi.org/10.31795/baunsobed.645486

Başaran, İ. E. (1991). “Örgütsel davranış”. A.Ü.Eğitim Fakültesi Yayını.

Bülbül, H. ve Tunç, T. (2017). Bölümlerarası Çatışmanın Yenilik Performansına Etkisi. Kastamonu Üniversitesi İktisadi ve İdari Bilimler Fakültesi Dergisi, 16(2), 7-25. https://doi.org/10.21180/kuiibf.20161218252

Cenkçi, T.; Dicle, Ü. ve Ökten, A. B. (2013). "Liderin Gücü ve Çatışma Yönetimi Yaklaşımlarının Bilişsim Teknolojisi Çalışanlarının Uyum ve İșten Ayrılma Niyetine Etkilerinin İncelenmesi”, 21. Ulusal Yönetim ve Organizasyon Kongresi Bildiriler Kitab1, 654-658. https://doi.org/10.25203/idd.370673

Ceylan, A, Ergün, E., Alpkan, L. (2000). Çatışmanın sebepleri ve yönetimi. Doğuş Üniversitesi Dergisi, 1 (2), 39-51. https://doi.org/10.31671/dogus.2019.379

Ceylan, C. (2002). Yönetsel ve organizasyonel açıdan koçluk yaklaşımı ve bir uygulama. Yayımlanmış doktora tezi. Uludağ Üniversitesi Sosyal Bilimler Enstitüsü. https://doi.org/10.18505/cuifd.48040

Christensen, L. B., Johnson, R. B. ve Turner, L.A. (2015). Araştırma yöntemleri desen ve analiz (Çev. A. Aypay) (1. Baskı). Anı Yayıncılık.

Güllüoğlu, Ö. (2013). Kayseri'de hizmet veren özel ilköğretim okulu öğretmenlerinin çatışma faktörlerinin ve çatışma yönetimi stratejilerinin analizi. Iletişim Kuram ve Araştırma Dergisi, 36, 193-218. https://doi.org/10.24315/tred.561001

Hanif, F.; Khan, M.; Adeel, M. and Shah, S. M. (2016), "Impact of Intra-Group Conflict on Group Performance - Moderating Role of Cultural Diversity", Universal Journal of Management, 4(2), 72-78.

He, Y.; Ding, X. and Yang, K, (2014). "Unpacking The Relationships Between Conflicts and Team Innovation”, Management Decision, 52(8), 1533-1548. https://doi.org/10.1108/md-032014-0127

Hom, P. W. and Kinicki, A. J., (2001). "Toward a Greater Understanding of How Dissatisfaction Drives Employee Turnover", Academy of Management Journal, 44(5), 975-987. https://doi.org/10.2307/3069441

Karcıoğlu, F. ve Alioğulları, Z. D. (2012). "Çatışmanın Nedenleri ve Çatışma Yönetim Tarzları İlişkisi”, Atatürk Üniversitesi İktisadi ve İdari Bilimler Dergisi, 26(3/4), 215-237. https://doi.org/10.18657/yonveek.305737 
Moreno, E. M.; Navarro, P. G.; Zornoza, A. and Ripoll, P. (2009). "Relationship, Task and Process Conflict on Team Performance: The Mediating Role of Communication Media", International Journal of Conflict Management, 20(3), 251-268. https://doi.org/10.1108/10444060910974876

Moustakas, C. (1994). Phenomenological research methods, Thousand Oaks California: Sage Publications.

Özdemir, N. (2018). Okullarda Öğretmenlerin Yaşadığı Çatışma ve Çatışma Yönetim Stilleri. Cumhuriyet Üniversitesi Edebiyat Fakültesi Sosyal Bilimler Dergisi, 42 (2), 93-116. https://doi.org/10.32600/huefd.433392

Özgan, H., Aslan, N. (2008). Analysis of the Effect of Secondary School Principles' Verbal Communication Styles on Teachers' Motivation. Gaziantep University Journal of Social Sciences, 7(1), 190-206.

Rogers, E. M. (2003). Diffusion of Innovations, 5th Edition, Free Press,. Wit vd. (2012),

Serinkan, C. (2008). Liderlik ve Motivasyon Geleneksel ve Güncel Yaklaşımlar. 1 Baskı, Nobel Yayın Dağıtım.

Wit, F. R.C.; Greer, L. L. and Jehn K. A. (2012). "The Paradox of Intragroup Conflict: A MetaAnalysis”, Journal of Applied Psychology, 97, 360-390. https://doi.org/10.1037/a0024844

Yıldırım, A. ve Şimşek, H. (2008). Sosyal bilimlerde nitel araştırma yöntemleri (7. Baskı). Seçkin Yayıncilik.

Zhang, S. J.; Chen, Y. Q., Sun, H. (2015). "Emotional Intelligence, Conflict Management Styles, and Innovation Performance: An Empirical Study of Chinese Employees”, International Journal of Conflict Management 26(4), 450-478. https://doi.org/10.1108/ijcma-06-2014-0039 